\title{
Growth Factors Regulate Expression of Osteoblast-Associated Genes
}

\author{
Christopher L. Strayhorn, ${ }^{*}$ J. Stephen Garrett, ${ }^{\dagger}$ Richard L. Dunn, ${ }^{\dagger}$ James J. Benedict, ${ }^{\dagger}$
} and Martha J. Somerman§

Background: The goal of periodontal regenerative therapies is to reconstruct periodontal tissues such as bone, cementum, and periodontal ligament cells (PDL). The need to establish predictable treatment modalities is important for reconstruction of these tissues. The aim of this study was to determine the effects of a low molecular extract of bovine bone protein (BP) containing bone morphogenetic proteins (BMPs) 2, 3, 4, 6, 7, 12, and 13 , alone or in combination with platelet-derived growth factor (PDGF) and/or insulin-like growth factor (IGF) on osteoblast differentiation in vitro.

Methods: BP, mixed with a collagen matrix, was added to a poly (DL-lactide-co-glycolide) polymer (PLG) and placed at orthotopic sites in the skullcaps of Sprague-Dawleys rats. At day 28 , rats were sacrificed for histological analysis. All sites treated with the polymer/BP produced bone while control sites (without BP) showed no bone formation. Having established the biological activity of BP, in vitro studies were initiated using MC3T3-E1 cells, a mouse osteoprogenitor cell line. The ability of BP and other growth factors to alter cell proliferation was determined by Coulter counter, and differentiation was determined by Northern analysis for specific genes.

Results: When compared with cells treated with $2 \%$ serum alone, PDGF enhanced cell numbers at 10 and $20 \mathrm{ng} / \mathrm{ml}$; IGF produced no significant effect at these doses; and BP at 10 and $20 \mu \mathrm{g} / \mathrm{ml}$ decreased cell proliferation. Northern analysis revealed that PDGF blocked gene expression of osteopontin (OPN) and osteocalcin (OCN), while BP and IGF promoted gene expression of bone sialoprotein (BSP) and OPN. The combination of BP and IGF enhanced expression of OPN beyond that of either BP or IGF alone. PDGF was able to block the effects of IGF on gene expression, but not those of BP.

Conclusions: These results indicate that BP, PDGF, and IGF influence cell activity differently, and thus raise the possibility that combining factors may enhance the biological activity of cells. J Periodontol 1999;70:1345-1354.

\section{KEY WORDS}

Growth factors; periodontal regeneration; osteoblasts; comparison studies; bone morphogenetic proteins.

\footnotetext{
* Department of Oral Medicine/Pathology and Oncology, University of Michigan, Ann Arbor, MI. † Atrix Corporation, Fort Collins, CO.

† Sulzer Orthopedics Biologics, Wheat Ridge, CO.

$\S$ Department of Periodontics/Prevention/Geriatrics and Department of Pharmacology, University of Michigan.
}

A n ultimate goal of periodontal regenerative therapies is to establish treatment modalities that predictably reconstruct periodontal tissues lost as a consequence of disease. This requires formation of bone, cementum, and a functional periodontal ligament (PDL). A key for reengineering these tissues is to first ascertain the necessary factors required for their development. As one approach, the studies described here focus specifically on determining the effects of agents on expression of genes associated with osteoblasts using a well-defined in vitro system. This in vitro model utilizes MC3T3-E1 cells, a mouse osteoblast progenitor cell line. Importantly, when MC3T3E1 cells in vitro are exposed to ascorbic acid and $\beta$-glycerol phosphate, they differentiate along the osteoblast pathway. This differentiation includes expression of osteoblast-associated genes, e.g., alkaline phosphatase (ALP), bone sialoprotein (BSP), osteocalcin (OCN), and osteopontin (OPN) and secretion of a matrix appropriate for promoting mineral nodule formation. ${ }^{1,2}$ Studies using a rat periodontal regenerative model have shown that these same genes are associated with bone formation in vivo. ${ }^{3}$ Thus, these cells provide an excellent system for initial screening of agents to determine whether or not specific factors can influence osteoblast differentiation. 
Attractive candidates for promoting osteoblast differentiation include polypeptide growth factors ${ }^{4,5}$ and bone morphogenetic proteins. ${ }^{6}$ The studies here focused on determining the role of platelet-derived growth factor (PDGF), insulin-like growth factor (IGF), and a partially purified extract of bovine bone (BP) containing a mixture of bone morphogenetic proteins (BMPs), alone and in combination, in regulating proliferation and gene expression in MC3T3-E1 cells. The rationale for selecting these factors was based on several points, including: 1) the known ability of polypeptide growth factors to promote events associated with wound healing including cell migration, cell proliferation, and extracellular matrix production; ${ }^{7}$ 2) existing evidence suggesting that PDGF/IGF can act synergistically to promote periodontal regeneration, bone formation, and cell proliferation both in vitro ${ }^{8-11}$ and in vivo; ${ }^{12-14}$ and 3 ) the known ability of bone morphogenetic proteins, such as those present in demineralized freeze-dried bone, to induce bone formation ${ }^{15,16}$ and also cementogenesis. ${ }^{17,18}$

PDGF containing two polypeptide chains as either a homodimer (AA or $B B$ ) or a heterodimer ( $A B$ ) exhibits strong mitogenetic activity in many cell types. The ability of PDGF to promote wound healing has been attributed to its proliferative activity, where it may function to increase the number of cells within the local environment at a healing site. IGF-I and -II are anabolic polypeptide growth factors structurally related to insulin. IGFs, produced in bone cells and stored in high concentrations within the bone matrix, are considered to regulate bone cells through both autocrine and paracrine pathways, resulting in an increase in osteoblast maturation. ${ }^{19-21}$ IGF activity and concentration at local sites have been shown to be regulated by several other factors including IGFBPs (IGF binding proteins), PDGF, and bone morphogenetic proteins (BMPs). Interestingly, PDGF appears to decrease expression of IGF mRNA in osteoblasts, while BMPs increase expression of IGF mRNA. Cell receptors for PDGF and IGFs have been identified and, while different from each other, are both tyrosine kinase signaling receptors. ${ }^{22-24}$

The BMPs, originally isolated from bone, belong to the TGF- $\beta$ superfamily and have a variety of functions dependent on tissue location and developmental stage. ${ }^{15,16,25-27}$ Studies to date provide convincing evidence that BMPs are powerful inducers of osteoblast differentiation in vitro 28,29 and bone formation in vivo, ${ }^{17,30-32}$ and thus may have potential for use in clinical situations where new bone formation is required. BMPs act through specific threonine-serine receptor kinases.

Previous in vitro and in vivo studies have demonstrated that PDGF/IGF act synergistically to promote periodontal regeneration, while data from in vitro studies using BMP and IGF in combination suggest that these 2 factors act synergistically to promote osteoblast differentiation. ${ }^{33,34}$ This prompted us to determine whether or not combinations of PDGF/ IGF/BP would prove to be useful for promoting periodontal regeneration. As a first step, the studies here focused on examining the effect of PDGF, IGF, and/or $\mathrm{BP}$ in various combinations on osteoblast activity in vitro. Factors that can enhance mineral tissue formation in vitro have potential for clinical use to promote both root mineralization and bone formation as required subsequent to loss of periodontal tissues. Results of studies here indicate that both IGF and BP promoted osteoblast differentiation as measured by expression of BSP, OPN, and OCN mRNA in MC3T3E1 cells, with an additive effect when used in combination. In contrast, PDGF promoted proliferation in MC3T3-E1 cells and blocked differentiation of osteoblasts as measured by decreased expression of OCN mRNA. Furthermore, when added with IGF, PDGF blocked the ability of IGF to induce expression of BSP, OPN, and OCN mRNA.

\section{MATERIALS AND METHODS}

\section{Assay for Bovine Bone Protein Activity}

BP was obtained as a dry lyophilized powder from a commercial source. ${ }^{\text {35-37 }}$ The biological activity was assessed using a rat orthotopic calvaria model. BP was prepared by dissolving $35 \mu \mathrm{g}$ of BP in $35 \mu \mathrm{l}$ of $10 \mathrm{mM} \mathrm{HCl}$ solution. This was added to $5 \mathrm{mg}$ of lyophilized collagen"l and allowed to soak into the collagen matrix. The resulting $\mathrm{BP} /$ collagen mixture was lyophilized and then added to $45 \mathrm{mg}$ of a 50:50 poly (DL-lactide-co-glycolide) polymer (PLG) with an inherent viscosity of $0.17 \mathrm{dl} / \mathrm{g} .{ }^{\#}$

Adult Sprague Dawley rat calvaria were exposed via a midline incision extending from the nasal bone to the mid-saggital crest and the skullcap was exposed with blunt dissection. The periosteum was removed from the internal flap surface and the polymer implant containing the lyophilized BP/collagen matrix was placed at the orthotopic site. Incisions were closed with 4-0 silk sutures. The animals were sacrificed at day 28 and their skullcaps surgically removed and processed for histological evaluation. Six micron step serial sections were made through the implant area and slides were analyzed for the overall amount of bone formation within the implant histomorphometrically.

\section{Culturing of MC3T3-E1 Cells}

MC3T3-E1 cells originally obtained from Dr. M. Kumegawa (Meikai University, Sakado, Japan) were

I| Colorado Biogenix, Denver, CO.

Il Bovine Type 1 Collagen, ReGen Biologics, Redwood City, CA.

\# Birmingham Polymers, Inc., Birmingham, AL. 
maintained as previously described. ${ }^{1}$ Briefly, cells were grown in $\alpha$-modified Eagle's medium $(\alpha-M E M) * *$ and $10 \%$ fetal bovine serum (FBS) containing $100 \mathrm{U} / \mathrm{ml}$ of penicillin and streptomycin. Cells were passaged every 4 to 5 days and not used beyond passage 15 . For cell proliferation assays and for Northern analyses, cells were cultured in media (mineralization media) containing $50 \mu \mathrm{g} / \mathrm{ml}$ ascorbic acid ${ }^{\dagger \dagger}$ and $10 \mathrm{mM} \beta$-glycerophosphate $^{\dagger \dagger}$ to induce osteoblastic differentiation and mineralization, respectively. ${ }^{38}$

\section{Cell Proliferation}

For proliferation assays, cells were plated in 24-well dishes, at 5,000 cells/ml in triplicate. For these studies, cells were exposed to mineralization media containing $2 \%$ FBS plus growth factors, unless stated otherwise.

In order to determine appropriate doses of growth factors to use for gene expression studies, cells were exposed to varying doses of PDGF and/or IGF over an 8-day period, and cell number determined over time. In a separate experiment, the effect of BP on cell number also was examined.

For these studies, initial doses used were PDGF-BB or IGF-I at 1,10 , or $20 \mathrm{ng} / \mathrm{ml}$; PDGF/IGF at 1,10 , or $20 \mathrm{ng} / \mathrm{ml}$ each; or BP at 1,10 , and $20 \mu \mathrm{g} / \mathrm{ml}$. These initial doses were selected based on previous in vitro studies from our laboratory group, as well as others.8,39 After the 24-hour adhesion period, medium was removed and replaced with appropriate agents plus $2 \%$ FBS. Medium, containing factors, was replaced on day 3 and 6 . Appropriate controls included cells exposed to media with $2 \%$ serum only (without ascorbic acid or $10 \mathrm{mM} \beta$-glycerophosphate), referred to in the text as negative control (CN), as well as cells exposed to media with $2 \%$ serum plus mineralization, i.e., $50 \mu \mathrm{g}$ ascorbic acid plus $10 \mathrm{M} \beta$-glycerophosphate, referred to in the text as vehicle control. Cells exposed to mineralization media containing $10 \%$ serum are referred to as positive controls. These same controls were used for Northern analysis of MC3T3-E1 cells after exposure to specific factors (see below). Cells were harvested on day 3, 6, and 8 and cell number determined by Coulter counter. PDGF and IGF were purchased from a commercial source. ${ }^{\ddagger}$

\section{Northern Blot Analysis}

For Northern analyses, cells were plated in $100 \mathrm{~mm}$ dishes at an initial density of 50,000 cells $/ \mathrm{cm}^{2}$. After a 24-hour attachment period, media were changed to mineralization media, $10 \%$ FBS or $2 \%$ FBS, supplemented with appropriate growth factors unless otherwise indicated. Specifically, cells were exposed to PDGF $(10 \mathrm{ng} / \mathrm{ml}), \operatorname{IGF}(10 \mathrm{ng} / \mathrm{ml})$, or BP $(10$ $\mu \mathrm{g} / \mathrm{ml}$ ), or to combinations of these factors at these same doses, i.e., PDGF/IGF or PDGF/BP or IGF/BP or PDGF/IGF/BP. RNA was isolated at day 8 and 16. In some experiments, BP was added after exposure of cells to IGF, PDGF, or IGF/PDGF for 6 days. RNA was isolated using the procedure of Xie and Rothblum. ${ }^{40}$ Briefly, for Northern analyses, total RNA was isolated using guanidinium isothiocyanate, sodium citrate, sodium acetate, phenol and chloroform extraction; quantitated by spectroscopy at $260 \mathrm{~nm}$; electrophoresed (10 to $20 \mu \mathrm{g}$ ) on $1.2 \%$ agarose formaldehyde gels; and transferred to nylon membranes.

The following cDNA probes were hybridized with the immobilized RNA: mouse osteopontin (OPN), ${ }^{41}$ mouse bone sialoprotein (BSP), ${ }^{42}$ human osteocalcin $(\mathrm{OCN}),{ }^{43}$ bovine type I collagen $\left(\alpha_{1} \mathrm{I}\right),{ }^{44}$ and osteoblastspecific transcription factor 2 (OSF2/Cbfa 1). ${ }^{45} \mathrm{GAPDH}$, a housekeeping gene, or ethidium bromide stained gels were used to determine relative RNA loading.

\section{Statistical Analysis}

For statistical analysis, one-way analysis of variance (ANOVA) and Tukey-Kramer multiple comparison tests were performed.

\section{RESULTS}

An orthotopic rat calvaria model was used to verify that BP had biological activity. As shown in Figure 1, BP promoted bone formation in this model system, confirming that the BP material had biologic activity. All sites treated with the polymer containing the $\mathrm{BP} /$ collagen matrix showed substantial bone formation. No control site treated with collagen/polymer matrix without BP showed bone formation.

Next, to determine the effects of IGF, PDGF, and BP on proliferation of MC3T3-E1 cells, cell counts were done at various time points over an 8-day period. BP at 1 to $20 \mu \mathrm{g}$ resulted in a decrease in cell number at day 8 when compared with vehicle control (2\%) and an increase in cell number when compared with negative control (CN) (Fig. 2A). At day 8, PDGF at $10 \mathrm{ng} / \mathrm{ml}$ and $20 \mathrm{ng} / \mathrm{ml}$ enhanced cell number when compared to control cells - both vehicle control (2\%) and negative control (CN) (Fig. 2B). No significant effect on cell number was noted in cells exposed to $1 \mathrm{ng} / \mathrm{ml}$ PDGF. In contrast, IGF at all doses examined here (1 to $20 \mathrm{ng} / \mathrm{ml}$ ) had no significant effect on cell number beyond that seen for both vehicle control (2\%) and negative control (CN) (Fig. 2C).

Existing evidence that PDGF and IGF in combination have a synergistic effect on cell proliferation ${ }^{10,13}$ prompted us to next examine whether such an effect would be obtained with MC3T3-E1 cells. As shown in Figure 2D, MC3T3-E1 cell number was increased by

* * Gibco BRL, Gaithersburg, MD.

$\dagger \dagger$ Sigma Chemical Co., St. Louis, MO.

$\neq \neq$ RED Systems, Minneapolis, MN. 


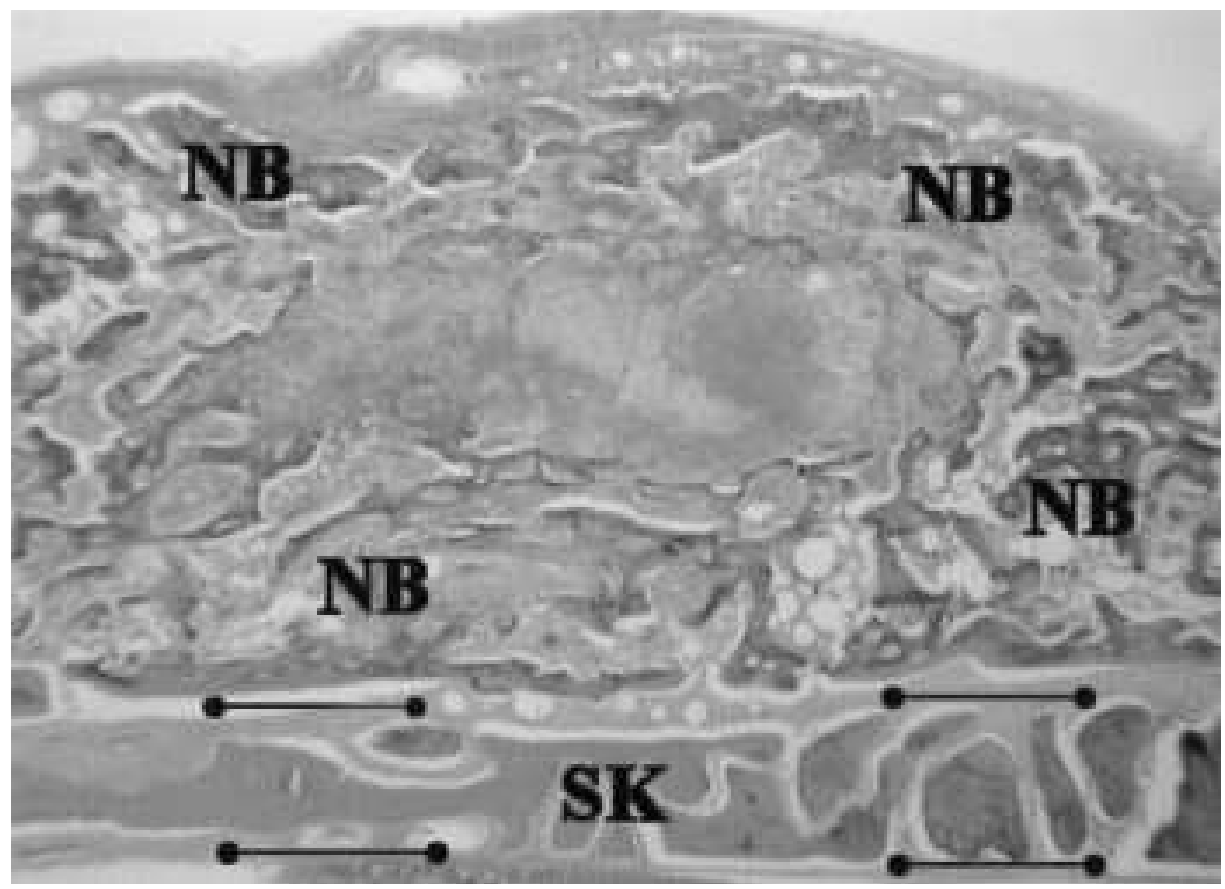

Figure I.

Bone formation in a polymer implant containing bone protein at an orthotopic site in adult Sprague Dawley rats. $S K=$ skull (parietal bone); $N B=$ new bone formation in the implant (original magnification $\times 16$ ).
PDGF's inhibitory effect on OCN expression was noted in cells exposed to PDGF/IGF combination. In contrast, PDGF's inhibitory effect on OCN was not as prominent in cells exposed to the combination of PDGF/BP or PDGF/IGF/BP (P/I/BP).

\section{OPN}

As shown in Figure 4, the effects of these agents on OPN expression were more dramatic. Both IGF and BP promoted OPN mRNA when compared with the vehicle control (2\%). Furthermore, the combination of IGF/BP resulted in an even greater promotion of OPN mRNA levels. Interestingly, PDGF blocked IGFmediated OPN mRNA (PDGF/IGF lane), while PDGF was not able to alter BP-mediated OPN mRNA expression (PDGF/BP lane). In addition, the additive effect of IGF/BP on OPN mRNA expression was blocked by PDGF (P/I/BP lane). Results at day 16 were comparable to those at day 8 (data not shown).
PDGF/IGF combination when compared with 2\% FBS control cells, but this effect was not greater than that noted for cells exposed to PDGF alone, at comparable doses (Fig. 2B).

As a positive control, cells were exposed to mineralization media plus 10\% FBS, and such cells exhibited increased cell numbers when compared with all other conditions. Statistical analyses at day 8 are shown in Table 1.

\section{Northern Analysis}

For analysis of genes expressed by MC3T3-E1 cells exposed to the various agents, doses used were as follows: PDGF $10 \mathrm{ng} / \mathrm{ml}$; IGF $10 \mathrm{ng} / \mathrm{ml}$; BP $10 \mu \mathrm{g} / \mathrm{ml}$; PDGF/IGF $10 \mathrm{ng} / \mathrm{ml}$ each; PDGF/BP (10 ng/ml/ $10 \mu \mathrm{g} / \mathrm{ml}) ; \operatorname{IGF} / B P(10 \mathrm{ng} / \mathrm{ml} / 10 \mu \mathrm{g} / \mathrm{ml})$; and PDGF/IGF/BP (10 ng/ml/10 ng/ml/10 $\mu \mathrm{g} / \mathrm{ml}$ ). These doses were selected to maintain consistency with the proliferation studies. In most experiments, cells were exposed to agents for the duration of the experiment, 8 days, with media changes every 3 to 4 days as described above.

\section{OCN/BSP}

As shown in Figure 3, PDGF blocked expression of OCN, a gene associated with osteoblast differentiation, when compared with vehicle control (2\%). Cells exposed to BP and IGF exhibited enhanced expression of BSP compared to vehicle control (2\%).

\section{OPN Pulse Experiments}

The next series of experiments were designed to determine whether an even greater effect on osteoblast differentiation would be observed if cells were exposed to growth factors early on, with BP added at a later stage (Fig. 4). For these experiments, cells were exposed to IGF $(10 \mathrm{ng} / \mathrm{ml}$ ) or PDGF (10 $\mathrm{ng} / \mathrm{ml}$ ) or PDGF/IGF $(10 \mathrm{ng} / \mathrm{ml} / 10 \mathrm{ng} / \mathrm{ml})$ for the total duration of the experiment, 8 days, with the addition of BP $(10 \mu \mathrm{g} / \mathrm{ml})$ the last 2 days. On day 8 , RNA was extracted and transcripts for OPN determined by Northern analysis. No differences in gene expression were noted between exposure of cells to IGF/BP for 8 days (IGF/BP lane) versus adding BP on day 6 (I/BP day 6 lane). Similarly, exposing cells to PDGF/BP for 8 days (PDGF/BP lane) versus adding $\mathrm{BP}$ on day 6 (P/BP day 6 lane) gave comparable results. PDGF's inhibitory effect on OPN mRNA expression was noted in PDGF/IGF/BP treated cells (P/I/BP lane), even after addition of BP on day 6 (P/I/BP day 6 lane).

\section{Osf2}

Studies by Ducy et al. ${ }^{45}$ have identified Osf2/Cbfa 1 (osteoblast specific transcription factor/core-binding factor) as an osteoblast-specific transcription factor and more specifically as a regulator of osteoblast differentiation. Thus, as a next step, the effect of exposing cells to PDGF, IGF, and BP on expression of Osf2 
was determined. As seen in Figure 5, BP and IGF did not affect expression of Osf2 mRNA, while PDGF inhibited Osf2 expression when compared with the vehicle control cells (2\%). Cells exposed to the combination of PDGF and IGF still exhibited decreased levels of Osf2 transcripts, while PDGF was not able to completely block Osf2 mRNA noted in cells exposed to BP. Also, cells exposed to $10 \%$ FBS exhibited lower levels of Osf2 mRNA when compared with cells exposed to $2 \%$ FBS.

\section{DISCUSSION}

The studies here were designed to determine the effects of IGF, PDGF, and BP, alone and in combination, on osteoblast differentiation, using an in vitro model system. Furthermore, it was anticipated that the in vitro model could serve as an assay for screening agents for their ability to promote osteoblast differentiation prior to initiating more costly in vivo studies with these agents.

A well-characterized mouse osteoblast progenitor cell line, MC3T3-E1, was used for these studies. Importantly, when these cells are cultured in the presence of ascorbic acid, they are stimulated to differentiate along the osteoblast pathway. ${ }^{1,2}$ With onset of differentiation, there is a cessation of cell replication, secretion of a type I collagen-associated extracellular matrix, and an upregulation of markers of osteoblast differentiation. Thus, in the presence of ascorbic acid, these cells are induced to express mRNA for BSP and OCN, known markers for the osteoblast phenotype. BSP, a glycoprotein selective to mineralized tissues, has been implicated as having a
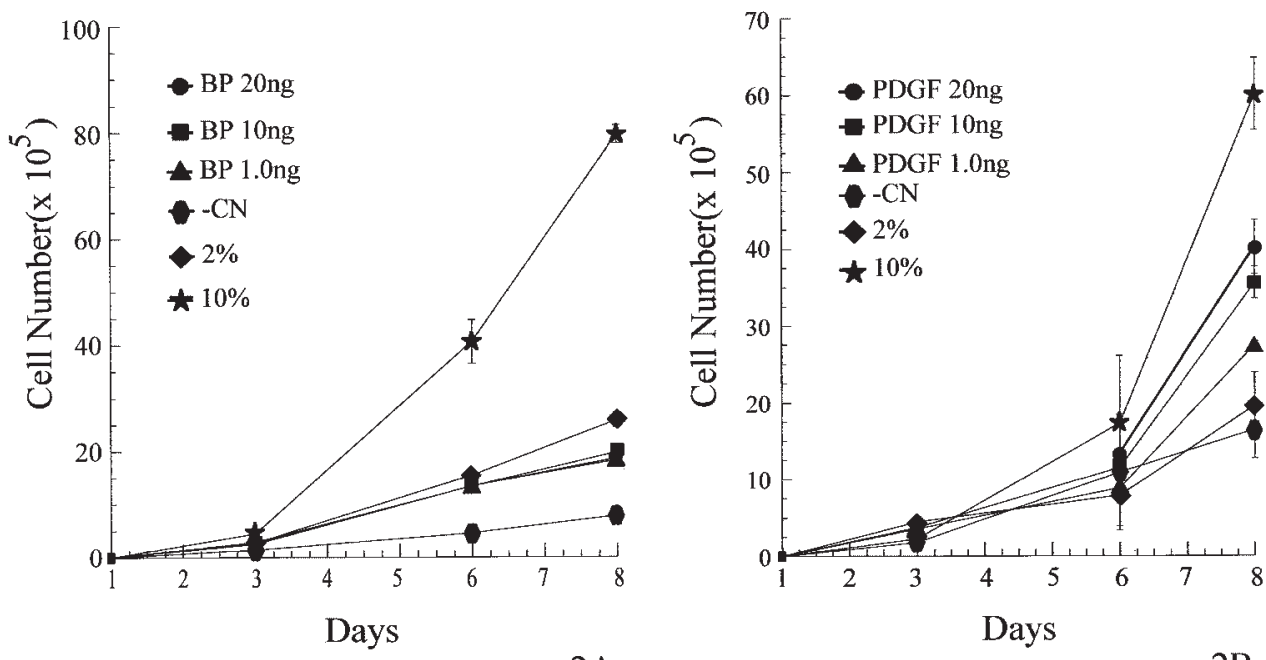

$2 \mathrm{~A}$

$2 B$
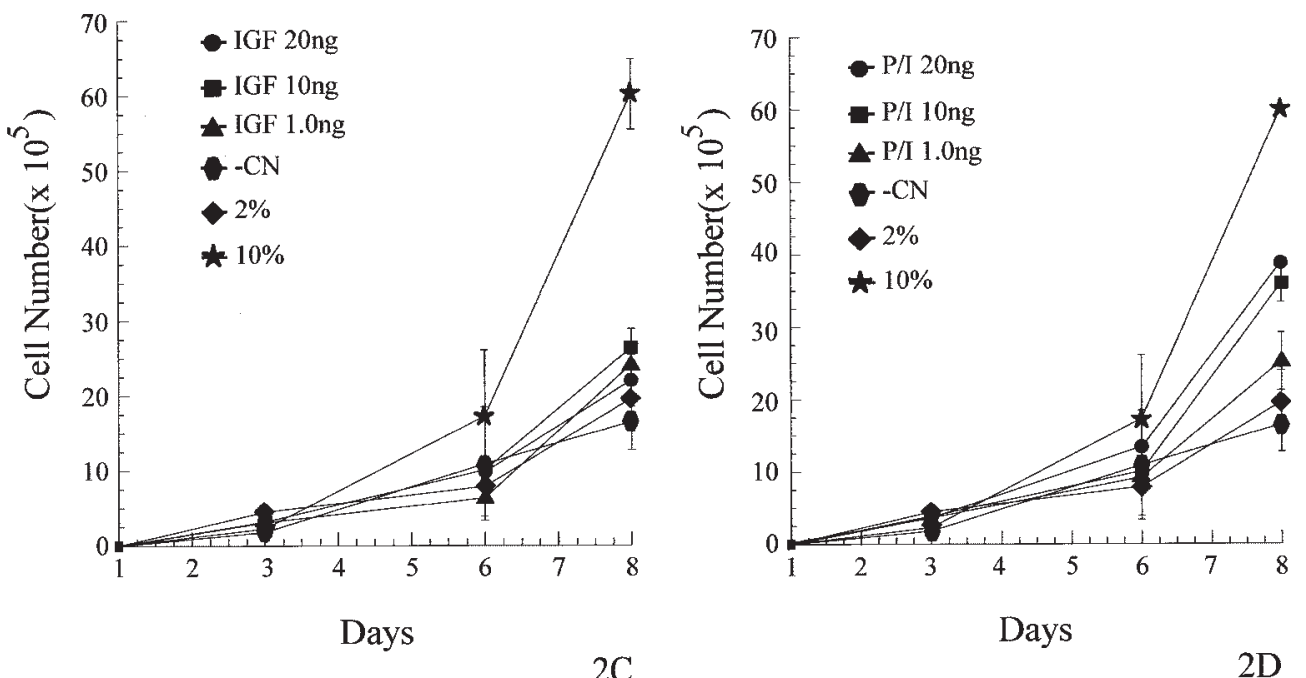

Figure 2.

Effect of PDGF, IGF, and BP on cell proliferation. Cells were plated at a density of 5,000 cells/ml and allowed to adhere overnight. On the following day, mineralization media with appropriate growth factors were added. Media were changed on day 3 and 6 and cells were harvested for cell counts on day 3, 6, and 8. A. BP; B. PDGF; C. IGF; D. PI (PDGF/IGF $10 \mathrm{ng} / / 0 \mathrm{ng})$.

Table I.

Effect of PDGF, IGF and BP on Cell Proliferation; Statistical Analysis at Day 8

\begin{tabular}{|c|c|c|c|c|c|c|c|c|}
\hline \multirow{3}{*}{ Controls } & \multicolumn{8}{|c|}{ Treatment } \\
\hline & \multicolumn{2}{|c|}{$\mathrm{BP}$} & \multicolumn{2}{|c|}{ PDGF } & \multicolumn{2}{|c|}{ IGF } & \multicolumn{2}{|c|}{ PDGF/IGF } \\
\hline & $10 \mu g$ & $20 \mu g$ & $10 \mathrm{ng}$ & $20 \mathrm{ng}$ & $10 \mathrm{ng}$ & $20 \mathrm{ng}$ & $10 \mathrm{ng}$ & $20 \mathrm{ng}$ \\
\hline Vehicle (2\%) & * & $\dagger$ & * & $\dagger$ & NS & NS & * & t \\
\hline Negative (CN) & $t$ & t & $\dagger$ & t & NS & NS & t & t \\
\hline
\end{tabular}

NS $=$ not significant $(P>0.05)$.

* $P<0.01 ; \dagger P<0.001$. 


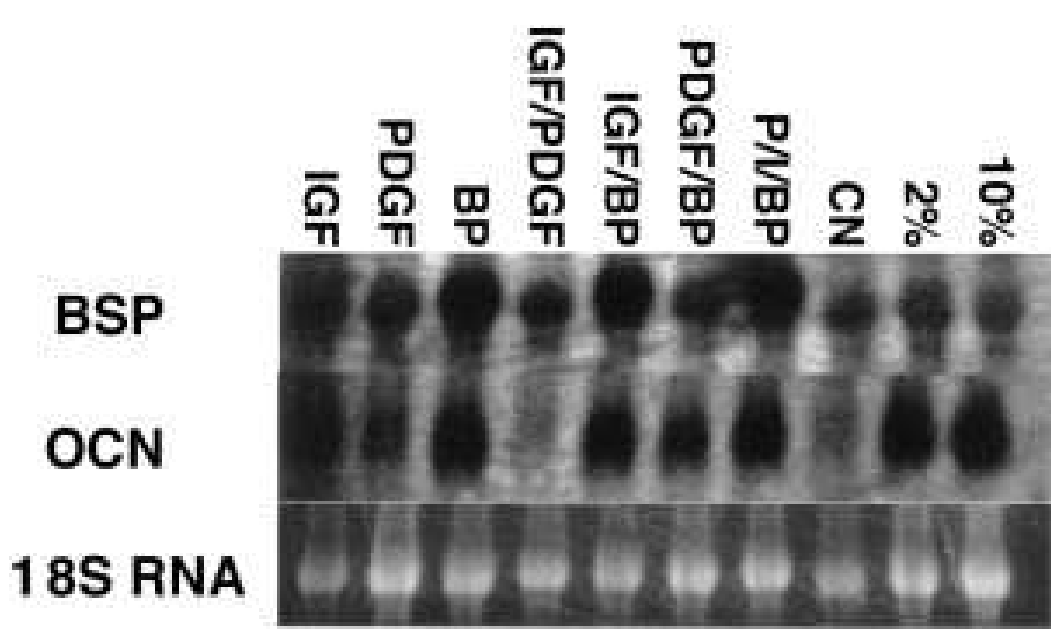

Figure 3.

Effect of PDGF, IGF, and BP on expression of BSP and OCN mRNA in MC3T3-EI cells. Cells were exposed to agents for 8 days and then RNA extracted for Northern blot analyses. IGF ( $10 \mathrm{ng} / \mathrm{ml})$; PDGF (10 ng/m/); BP (10 $\mathrm{\mu g} / \mathrm{ml})$ - same dose used alone or in combination studies. I $8 S$ RNA is shown to indicate relative loading of RNA. increased expression of osteoblast-specific markers, while PDGF inhibits differentiation of MC3T3-E1 cells along the osteoblast pathway. Furthermore, when IGF-stimulated cells also are exposed to PDGF, expression of osteoblastspecific markers induced by IGF is blocked. In contrast, PDGF was not able to block BPinduced expression of osteoblast-specific markers. When BP was added in combination with IGF, the increased expression of OPN, OC and BSP transcripts was still noted, where an additive effect on OPN mRNA expression was detected in these cells when compared with cells treated with either BP or IGF alone. This additive effect on OPN transcripts may prove to have clinical significance. For example, while highly speculative, agents that regulate crystal growth, ${ }^{53}$ such as OPN, may provide an appropriate balance between mineral formation and PDL attachment, thus preventing ankylosis, as has been reported with use of various other osteoinductive factors.

Interestingly, at the time we noted this additive effect on OPN mRNA expression, two papers appeared supporting this finding. Yeh et al. $^{33}$ demonstrated that BMP-7/OP-1 and IGF-I acted synergistically to promote $\left[{ }^{3} \mathrm{H}\right]$ thymidine incorporation, alkaline phosphatase activity, PTH-dependent cAMP level, and bone nodule formation, using primary cultures of fetal rat calvaria cells, where maximal synergy was noted when they were added simultaneously. They did not report on the effects of these factors on OCN, BSP, or OPN mRNA levels. In another study, Hayden et al. ${ }^{54}$ demonstrated that BMP-7 stimulates IGFBP-3 production in human osteosarcoma cells predominantly by promoting the production of IGFBP-3 nuclear transcripts. The importance of this activity to BMP-7's ability to promote differentiation remains to be established.

Based on previous reports indicating that PDGF/IGF in combination promote periodontal regeneration, ${ }^{13,14,55-57}$ we were surprised that the combination of PDGF/IGF blocked expression of genes associated with osteoblasts. However, the positive effects of PDGF seen at sites of wound healing are attributed to its ability to promote cell migration and proliferation, thus establishing a critical mass of cells at a local site. ${ }^{8-10,58-64}$ In fact, several studies report that PDGF, while promoting cell replication, inhibits osteoblast differentiation. ${ }^{22,65-67}$ Furthermore, Hock and Canalis ${ }^{22}$ demonstrated that PDGF decreased IGF mRNA in osteoprogenitor cells and suggested that this effect may, in part, explain PDGF-mediated inhibition of osteoblast differentiation. Thus, our studies support 


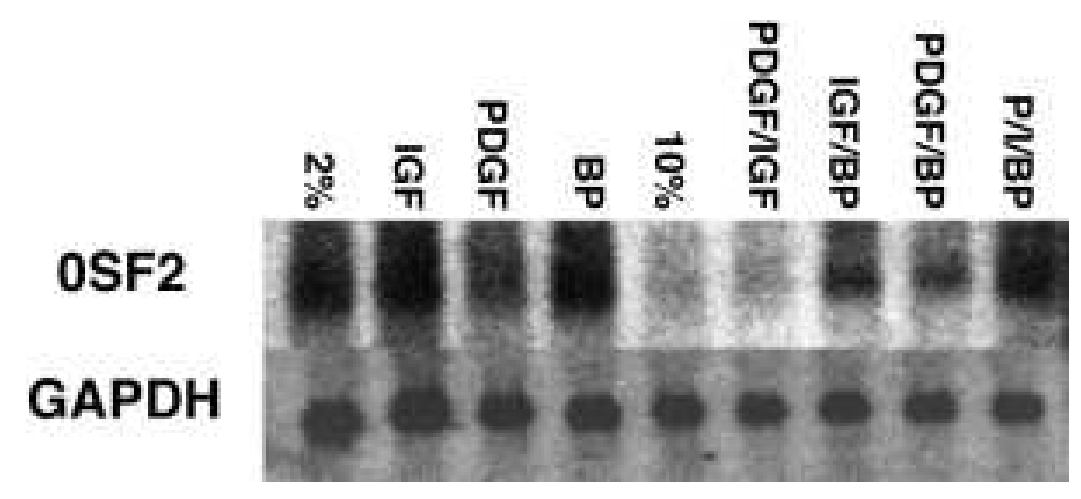

Figure 5.

Effect of PDGF, IGF, and BP on Osf2 mRNA in MC3T3-E I cells. For these experiments, cells were treated as described in Figure 3. GAPDH is shown to indicate relative loading of RNA.

this finding where we show PDGF, but not IGF or BP, promoted proliferation of MC3T3-E1 cells, but blocked osteoblast differentiation. This result prompted us to design experiments to determine whether osteoblast differentiation would be enhanced if cells were exposed to PDGF or IGF or PDGF/IGF for 6 days, followed by BP. As seen in Figure 4, this treatment did not enhance gene expression beyond that noted in cells continually cotreated with BP/IGF. Moreover, addition of BP at day 6 did not counteract the inhibitory effect of PDGF on IGF's abilities to promote expression of specific genes. This may be attributed to PDGF's ability to block IGF transcripts, as well as the noted ability of PDGF to regulate IGF binding proteins. ${ }^{23,24}$ It is clear from the results presented here and reported by others ${ }^{22}$ that PDGF inhibits osteoblast differentiation. This does not rule out the possibility that PDGF may be of value in regenerative procedures. For example, PDGF may act early on in the regenerative process to promote cell migration and/or cell replication, prior to addition of factors that subsequently promote osteoblast differentiation. The inability to demonstrate an additive effect on expression of osteoblast-associated transcripts by using PDGF followed by BP in the studies described here may be attributed to several factors. Those factors include: 1) doses selected may be inappropriate for observing additive effects; 2 ) duration of exposure to BP or IGF, e.g., in the pulse study; here, cells were treated with PDGF or IGF for 6 days, followed by BP for 2 days; longer exposure to these later factors and also removal of PDGF may have resulted in more impressive results; 3 ) serum itself may alter activity of added PDGF and IGF; and 4) cell type selected for studies. It is well known that activity of growth factors is dependent on stage of cell differentiation, as well as cell phenotype. Therefore, it is possible that with an alternative experimental design, an additive effect would have been seen when using PDGF in combination with BP and/or IGF.

In contrast to PDGF, BP and IGF promoted expression of transcripts associated with the osteoblast phenotype. The BP used here is an extract of bovine bone and contains BMP-2, - $3,-4,-6,-7,-12$, and -13 with virtually no IGF or PDGF. ${ }^{35}$ Thus, it was anticipated that BP would promote osteoblast differentiation. Early studies directed at identifying inducers of osteoblast differentiation in bone established that bone contained "bone morphogenetic proteins (BMPs)" that were capable of inducing endochondral bone formation in vivo and cartilage in vitro. ${ }^{68-70}$ Subsequent studies have resulted in identification of several BMPs, where it is now recognized that in addition to their critical role in mineralized tissues, 15,26,27 they are widely distributed in other tissues as well and have several other functions including acting as signaling molecules in epithelial-mesenchymal interactions during early organogenesis. ${ }^{71-75}$ In vitro studies using recombinant BMPs have demonstrated that BMP-2, -4 , -6 , and -7 are potent inducers of osteoblast differentiation. ${ }^{29,33,76-81}$ In vivo studies have reinforced these findings, demonstrating that BMPs promote regeneration of bone and also periodontal tissues including bone, cementum, and periodontal ligament, with reported risk of accompanying ankylosis. ${ }^{18,30,32,56,82-85}$ The material used in our studies was extracted under conditions that are selective for BMPs. Studies were conducted to first demonstrate biological activity and second, to demonstrate consistency from batch to batch. As shown here, this material can induce bone formation in vivo and induce osteoblast differentiation in vitro, and these findings were reproducible.

In order to further define the mechanism(s) controlling the activities of PDGF, IGF, and BP on bone activity, expression of Osf2 transcripts was determined in cells exposed to PDGF and/or IGF and/or BP. Osf2 is considered an osteoblast-specific transcription factor. When added to C3H10T1/2 fibroblasts, in vitro BMP-7 has been shown to promote expression of Osf2 mRNA, followed by expression of transcripts for osteoblast specific markers. ${ }^{45}$ As shown in Figure 5, PDGF blocked expression of Osf2 mRNA, while IGF and BP maintained Osf2 mRNA levels in MC3T3-E1 cells. Thus, the effect of specific factors on Osf2 mRNA expression may serve as an indicator of their ability to promote osteoblast differentiation.

In summary, the studies here demonstrate that BP is a potent inducer of osteoblast differentiation and may act synergistically with IGF to promote osteoblast differentiation. Further studies, including the use of various doses of BP/IGF and/or PDGF in 
vivo and in vitro, are warranted to determine if there are any benefits in using these factors in combination for periodontal regenerative procedures.

\section{ACKNOWLEDGMENTS}

The authors thank Bhagya Chandrashekar and Katheleen McEnery for preparation of the polymer/ bone protein matrix; Jan Berry for research advice and discussions; and Mary Schmidt for preparation of the manuscript. Support for this research was provided by NIDR grant 2 R44 DE09187-0ZAZ to Dr. Dunn.

Dr. Garrett is Senior Vice President and Dr. Dunn is Vice President of Atrix Corporation. Dr. Benedict is Vice President of Sulzer Orthopedics.

\section{REFERENCES}

1. Franceschi RT, Iyer BS. Relationship between collagen synthesis and expression of the osteoblast phenotype in MC3T3-E1 cells. J Bone Miner Res 1992; 7:235-246.

2. Franceschi RT, lyer BS, Chi Y. Effects of ascorbic acid on collagen matrix formation and osteoblast differentiation in murine MC3T3-E1 cells. J Bone Miner Res 1994;9: 843-854.

3. Lekic P, Sodek J, McCulloch CAG. Osteopontin and bone sialoprotein expression in regenerating rat periodontal ligament and alveolar bone. Anat Rec 1996; 244:50-58.

4. Graves DT, Cochran DL. Periodontal regeneration with polypeptide growth factors. Curr Opin Periodontol 1994;1:178-186.

5. Howell TH, Martuscelli G, Oringer J. Polypeptide growth factors for periodontal regeneration. Curr Opin Periodontol 1996;3:149-156.

6. McCauley LK, Somerman MJ. Biological modifiers in periodontal regeneration. Dent Clin North Am 1998;42: 361-387.

7. Lynch SE, Giannobile WV. Polypeptide growth factors: Molecular mediators of tissue repair. In: Genco RJ, Hamada S, Lehner T, McGhee J, Mergenhagen S, eds. Molecular Pathogenesis of Periodontal Disease. Washington, DC: American Society for Microbiology; 1994:415-425.

8. Matsuda N, Lin OL, Kumar NM, Cho MI, Genco RJ. Mitogenic, chemotactic, and synthetic responses of rat periodontal ligament fibroblastic cells to polypeptide growth factors in vitro. J Periodontol 1992;63: 515-525.

9. Oates TW, Rouse CA, Cochran DL. Mitogenic effects of growth factors on human periodontal ligament cells in vitro. J Periodontol 1993;64:142-148.

10. Pfeilschifter J, Oechsner M, Naumann A, Gronwald RG, Minne HW, Ziegler R. Stimulation of bone matrix apposition in vitro by local growth factors: A comparison between insulin-like growth factor I, platelet-derived growth factor, and transforming growth factor beta. Endodont 1990;127:69-75.

11. Kordylewska AM, Mass DP. PDGF enhances effects of synergistic growth factors in DNA and protein synthesis: Rabbit flexor tendons in vitro. Wound Rep Reg 1994; 2:109.

12. Lynch SE, Trippel SB, Finkelman RD, Hernandez RA, Kiritsy CP, Antoniades HN. The combination of plateletderived growth factor-BB and insulin-like growth factor-I stimulates bone repair in adult Yucatan miniature pigs.
Wound Rep Reg 1994;2:182-190.

13. Lynch SE, Williams RC, Polson AM, et al. A combination of platelet-derived and insulin-like growth factors enhances periodontal regeneration. J Clin Periodontol 1989;16:545-548.

14. Lynch SE, de Castilla GR, Williams RC, et al. The effects of short-term application of a combination of plateletderived and insulin-like growth factors on periodontal wound healing. J Periodontol 1991;62:458-467.

15. Ripamonti $U$, Reddi AH. Tissue engineering, morphogenesis and regeneration of the periodontal tissues by bone morphogenetic proteins. Crit Rev Oral Biol Med 1997;8:154-163.

16. Lee MB. Bone morphogenetic proteins: Background and implications for oral reconstruction. A review. J Clin Periodontol 1997;24:355-365.

17. Giannobile WV, Ryan S, Shih M-S, Su DL, Kaplan PL, Chan TCK. Recombinant human osteogenic protein-1 (OP-1) stimulates periodontal wound healing in class III furcation defects. J Periodontol 1998;69:129-137.

18. Ripamonti $U$. Induction of cementogenesis and periodontal ligament regeneration by bone morphogenetic proteins. In: Lindholm TS, ed. Bone Morphogenetic Proteins: Biology, Biochemistry and Reconstructive Surgery. Austin, TX: R.G. Landes Company; 1996:189-198.

19. Canalis E, McCarthy TL, Centrella M. Isolation of growth factors from adult bovine bone. Calcif Tissue Int 1988;43:346-351.

20. Hock JM, Centrella M, Canalis E. Insulin-like growth factor I has independent effects on bone matrix formation and cell replication. Endodont 1988;122:254-260.

21. McCarthy TL, Cenrella M, Canalis E. Parathyroid hormone enhances the transcription and polypeptide levels of insulin-like growth factor I in osteoblast-enriched cultures from fetal rat bone. Endodont 1989;124: 1247-1253.

22. Hock JM, Canalis E. Platelet-derived growth factor enhances bone cell replication, but not differentiated function of osteoblasts. Endodont 1994;134:1473-1478.

23. Conover CA. The role of insulin-like growth factors and binding proteins in bone cell biology. In: Bilezikian JP, Raisz LG, Rodan GA, eds. Principles of Bone Biology. San Diego: Academic Press; 1996:607-618.

24. Canalis E, Rydziel S. Platelet-derived growth factor and the skeleton. In: Bilezikian JP, Raisz LG, Rodan GA, eds. Principles of Bone Biology. San Diego: Academic Press; 1996:619-626.

25. Hogan BLM. Bone morphogenetic proteins in development. Curr Opin Genet Dev 1996;6:432-438.

26. Wozney JM, Rosen V, Celeste AJ, et al. Novel regulators of bone formation: Molecular clones and activities. Science 1988;242:1528-1534.

27. Wozney JM. The bone morphogenetic protein family and osteogenesis. Mol Reprod Dev 1992;32:160-167.

28. Asahina I, Sampath TK, Hauschka PV. Human osteogenic protein-1 induces chondroblastic, osteoblastic, and/or adipocytic differentiation of clonal murine target cells. Exp Cell Res 1996;222:38-47.

29. Hughes FJ, Collyer J, Stanfield M, Goodman SA. The effects of bone morphogenetic protein-2, -4 , and -6 on differentiation of rat osteoblast cells in vitro. Endodont 1995;136:2671-2677.

30. King GN, King N, Cruchley AT, Wozney JM, Hughes FJ. Recombinant human bone morphogenetic protein-2 promotes wound healing in rat periodontal fenestration defects. J Dent Res 1997;76:1460-1470. 
31. Ripamonti U, Heliotis M, Rueger DC, Sampath TK. Induction of cementogenesis by recombinant human osteogenic protein-1 (hop-1/bmp-7) in the baboon (Papio ursinus). Arch Oral Biol 1996;41:121-126.

32. Ripamonti U, Van Den Heever B, Sampath TK, Tucker MM, Rueger DC, Reddi AH. Complete regeneration of bone in the baboon by recombinant human osteogenic protein-1 (hOP-1, bone morphogenetic protein-7). Growth Factors 1996;13:273-289.

33. Yeh L-CC, Adamo ML, Olson MS, Lee JC. Osteogenic protein-1 and insulin-like growth factor I synergistically stimulate rat osteoblastic cell differentiation and proliferation. Endodont 1997;138:4181-4190.

34. Canalis E, Gabbitas B. Bone morphogenetic protein 2 increases insulin-like growth factor I and II transcripts and polypeptide levels in bone cell cultures. J Bone Miner Res 1994;9:1999-2005.

35. Barnes TS, Lewis MJ, Benedict JJ. The identification of proteins in "BP," an osteoinductive fraction derived from bovine bone. Bone 1999;24:395-397.

36. Atkinson BL, Fantle KS, Benedict JJ, Huffer WE, Gutierrez-Hartmann A. Combination of osteoinductive bone proteins differentiates mesenchymal C3H/10T1/2 cells specifically to the cartilage lineage. J Cell Biochem 1997;65:325-339.

37. Sciadini MF, Dawson JM, Johnson KD. Evaluation of bovine-derived bone protein with a natural coral carrier as a bone-graft substitute in a canine segmental defect model. J Orthop Res 1997;15:844-857.

38. Bellows CG, Heersche JN, Aubin JE. Inorganic phosphate added exogenously or released from betaglycerophosphate initiates mineralization of osteoid nodules in vitro. Bone Miner 1992;17:15-29.

39. MacNeil RL, D'Errico J, Strayhorn C, Pickrum H, Somerman MJ. Agents with periodontal regenerative potential regulate cell-mediated collagen lattice contraction in vitro. J Dent Res 1996;75:903-911.

40. Xie WQ, Rothblum LI. Rapid, small-scale RNA isolation from tissue culture cells. Biotechniques 1991;11:324, 326-327.

41. Crosby AH, Lyu MS, Lin K, et al. Mapping of the human and mouse bone sialoprotein and osteopontin loci. Mamm Genome 1996;7:149-151.

42. Young MF, Ibaraki K, Kerr JM, Lyu MS, Kozak CA. Murine bone sialoprotein (BSP): cDNA cloning, mRNA expression, and genetic mapping. Mamm Genome 1994;5:108-111.

43. Celeste AJ, Rosen V, Bueker JL, Kriz R, Wang EA, Wozney JM. Isolation of the human gene for bone gla protein utilizing mouse and rat cDNA clones. EMBO $J$ 1986;5:1885-1890.

44. Liau G, Yamada Y, deCrombrugghe B. Coordinate regulation of the levels of type III and type I collagen mRNA in most but not all mouse fibroblasts. J Biol Chem 1985;260:531-536.

45. Ducy P, Zhang R, Geoffroy V, Ridall AL, Karsenty G. Osf2/Cbfa1: A transcriptional activator of osteoblast differentiation. Cell 1997;89:747-754.

46. Bianco P, Fisher LW, Young MF, Termine JD, Robey PG. Expression of bone sialoprotein (BSP) in developing human tissues. Calcif Tissue Int 1991;49:421-426.

47. Ganss B, Kim RH, Sodek J. Bone sialoprotein. Crit Rev Oral Biol 1998;10:79-98.

48. Hunter GK, Goldberg HA. Nucleation of hydroxyapatite by bone sialoprotein. Biochem 1993;90:8562-8565.

49. MacNeil RL, Berry JE, Strayhorn CL, Somerman MJ. Expression of bone sialoprotein mRNA by cells lining the mouse tooth root during cementogenesis. Arch Oral Biol 1996;41:827-835.

50. McKee MD, Nanci A. Osteopontin and the bone remodeling sequence. Colloidal-gold immunocytochemistry of an interfacial extracellular matrix protein. Ann NY Acad Sci 1995;760:177-189.

51. McKee MD, Nanci A. Postembedding colloidal-gold immunocytochemistry of noncollagenous extracellular matrix proteins in mineralized tissues. Microsc Res Tech 1995;31:44-62.

52. Bosshardt DD, Zalzal S, McKee MD, Nanci A. Developmental appearance and distribution of bone sialoprotein and osteopontin in human and rat cementum. Anat Rec 1998;250:13-33.

53. Butler WT, Ridall AL, McKee MD. Osteopontin. In: Bilezikian JP, Raisz LG, Rodan GA, eds. Principles of Bone Biology. San Diego: Academic Press; 1996:167182.

54. Hayden JM, Strong DD, Baylink DJ, Powell DR, Sampath TK, Mohan S. Osteogenic protein-1 stimulates production of insulin-like growth factor binding protein-3 nuclear transcripts in human osteosarcoma cells. Endodont 1997;138:4240-4247.

55. Rutherford RB, Sampath TK, Rueger DC, Taylor TD. Use of bovine osteogenic protein to promote rapid osseointegration of endosseous dental implants. Int $J$ Oral Maxillofac Implants 1992;7:297-301.

56. Giannobile WV, Finkelman RD, Lynch SE. Comparison of canine and non-human primate animal models for periodontal regenerative therapy: Results following a single administration of PDGF/IGF-I. J Periodontol 1994; 65:1158-1168.

57. Giannobile WV. Periodontal tissue engineering by growth factors. Bone 1996;19:23S-37S.

58. Wang HL, O'Neal RB, Thomas CL, Shyr Y, MacNeil RL. Evaluation of an absorbable collagen membrane in treating Class II furcation defects. J Periodontol 1994; 65: 1029-1036.

59. Blom S, Holmstrup P, Dabelsteen E. A comparison of the effect of epidermal growth factor, platelet-derived growth factor, and fibroblast growth factor on rat periodontal ligament fibroblast-like cells' DNA synthesis and morphology. J Periodontol 1994;65:373-378.

60. Piche JE, Graves DT. Study of the growth factor requirements of human bone-derived cells: A comparison with human fibroblasts. Bone 1989;10: $131-138$.

61. Mailhot JM, Sharawy MM, Galal M, Oldham AM, Russell CM. Porous polysulfone coated with platelet-derived growth factor-BB stimulates proliferation of human periodontal ligament fibroblasts. J Periodontol 1996; 67:981-985.

62. Boyan LA, Bhargava G, Nishimura F, Orman R, Price R, Terranova VP. Mitogenic and chemotactic responses of human periodontal ligament cells to the different isoforms of platelet-derived growth factor. $J$ Dent Res 1994;73:1593-1600.

63. Hughes FJ, Aubin JE, Heersche JN. Differential chemotactic responses of different populations of fetal rat calvaria cells to platelet-derived growth factor and transforming growth factor beta. Bone Miner 1992; 19:63-74.

64. Dennison DK, Vallone DR, Pinero GJ, Rittman B, Caffesse RG. Differential effect of TGF- $\beta 1$ and PDGF on proliferation of periodontal ligament cells and gingival fibroblasts. J Periodontol 1994;65:641-648.

65. Giannobile WV, Whitson SW, Lynch SE. Non-coordinate 
control of bone formation displayed by growth factor combinations with IGF-I. J Dent Res 1997;76:15691578.

66. Tanaka H, Liang CT. Effect of platelet-derived growth factor on DNA synthesis and gene expression in bone marrow stromal cells derived from adult and old rats. J Cell Physiol 1995;164:367-375.

67. Alvares O, Klebe R, Grant G, Cochran DL. Growth factor effects on the expression of collagenase and TIMP-1 in periodontal ligament cells. J Periodontol 1995;66: 552-558.

68. Urist MR. Bone: Formation by autoinduction. Science 1965; 150:893-899.

69. Urist MR, DeLange RJ, Finerman GA. Bone cell differentiation and growth factors. Science 1983;220: 680-686.

70. Reddi AH, Huggins C. Biochemical sequences in the transformation of normal fibroblasts in adolescent rats. J Histochem Cytochem 1972;69:1601-1605.

71. Vainio S, Karavanova I, Jowett A, Thesleff I. Identification of BMP-4 as a signal mediating secondary induction between epithelial and mesenchymal tissues during early tooth development. Cell 1993;75:45-58.

72. Vukicevic S, Helder MN, Luyten FP. Developing human lung and kidney are major sites for synthesis of bone morphogenetic protein-3 (osteogenin). J Histochem Cytochem 1994;42:869-875.

73. Vukicevic S, Latin V, Chen P, Batorsky R, Reddi AH, Sampath TK. Localization of osteogenic protein-1, a bone morphogenetic protein, during human embryonic development. Biochem Biophys Res Commun 1994;198:693-700.

74. Heikinheimo M, Lawshe A, Shackleford GM, Wilson DB, MacArthur CA. Fgf-8 expression in the post-gastrulation mouse suggests roles in the development of the face, limbs and central nervous system. Mech Dev 1994; 48:129-138.

75. Helder MN, Ozkaynak E, Sampath TK, et al. Expression pattern of osteogenic protein-1 (bone morphogenetic protein-7) in human and mouse development. J Histochem Cytochem 1995;43:1035-1044.

76. Torii Y, Hitomi K, Tsukagoshi N. Synergistic effect of BMP-2 and ascorbate on the phenotypic expression of osteoblastic MC3T3-E1 cells. Mol Cell Biochem 1996;165:25-29.

77. Knutsen R, Honda Y, Strong DD, Sampath TK, Baylink DJ, Mohan S. Regulation of insulin-like growth factor components by osteogenic protein-1 in human bone cells. Endodont 1995;136:857-865.

78. Sampath TK, Maliakal JC, Hauschka PV, et al. Recombinant human osteogenic protein-1 (hOP-1) induces new bone formation in vivo with a specific activity comparable with natural bovine osteogenic protein and stimulates osteoblast proliferation and differentiatioin in vitro. J Biol Chem 1992;267:2035220362.

79. Asahina I, Sampath TK, Nishimura I, Hauschka PV. Human osteogenic protein-1 induces both chondroblastic and osteoblastic differentiation of osteoprogenitor cells derived from newborn rat calvaria. J Cell Biol 1993; 123:921-933.

80. Boden SD, McCuaig K, Hair G, et al. Differential effects and glucocorticoid potentiation of bone morphogenetic protein action during rat osteoblast differentiation in vitro. Endodont 1996;137:3401-3407.

81. Zegzula HD, Buck DC, Brekke J, Wozney JM, Hollinger JO. Bone formation with use of rhBMP-2 (recombinant human bone morphogenetic protein-2). J Bone Joint Surg 1997;79:1778-1790.

82. Sigurdsson TJ, Lee MB, Kubota K, Turek TJ, Wozney JM, Wikesjö UME. Periodontal repair in dogs: Recombinant human bone morphogenetic protein-2 significantly enhances periodontal regeneration. J Periodontol 1995;66:131-138.

83. Sigurdsson TJ, Tatakis DN, Lee MB, Wikesjö UM. Periodontal regenerative potential of space-providing expanded polytetrafluoroethylene membranes and recombinant human bone morphogenetic proteins. J Periodontol 1995;66:511-521.

84. Giannobile WV. Periodontal tissue regeneration by polypeptide growth factors and gene transfer. In: Lynch SE, Genco RJ, Marx R, eds. Tissue Engineering: Applications in Maxillofacial Surgery and Periodontics. Chicago: Quintessence International; 1999:231-246.

85. Giannobile WV, Ryan S, Shih MS, Su DL, Kaplan P, Chan T. Osteogenic protein-1 (OP-1) promotes periodontal wound healing in Class III furcations. J Periodontol 1998;69:129-137.

Send reprint requests to: Dr. Martha J. Somerman, Department of Periodontics/Prevention/Geriatrics, University of Michigan, 1011 N. University Ave., Ann Arbor, MI 481091078. Fax: 734/763-5503.

Accepted for publication March 22, 1999. 